University of Nebraska - Lincoln

DigitalCommons@University of Nebraska - Lincoln

Agronomy \& Horticulture -- Faculty Publications

Agronomy and Horticulture Department

2002

\title{
Soil Organic Matter Assessments In A Long-Term Cropping System Study
}

Gary E. Varvel

University of Nebraska-Lincoln, gevarvel@windstream.net

Mark A. Liebig

USDA-Agricultural Research Service, Northern Great Plains Research Laboratory

John W. Doran

University of Nebraska-Lincoln, jdoran1@unl.edu

Follow this and additional works at: https://digitalcommons.unl.edu/agronomyfacpub

Part of the Plant Sciences Commons

Varvel, Gary E.; Liebig, Mark A.; and Doran, John W., "Soil Organic Matter Assessments In A Long-Term Cropping System Study" (2002). Agronomy \& Horticulture -- Faculty Publications. 333.

https://digitalcommons.unl.edu/agronomyfacpub/333

This Article is brought to you for free and open access by the Agronomy and Horticulture Department at DigitalCommons@University of Nebraska - Lincoln. It has been accepted for inclusion in Agronomy \& Horticulture -Faculty Publications by an authorized administrator of DigitalCommons@University of Nebraska - Lincoln. 


\title{
SOIL ORGANIC MATTER ASSESSMENTS IN A LONG-TERM CROPPING SYSTEM STUDY*
}

\author{
Gary E. Varvel, ${ }^{1, \dagger}$ Mark A. Liebig, ${ }^{2}$ and John W. Doran ${ }^{1}$ \\ ${ }^{1}$ USDA-Agricultural Research Service and Department of \\ Agronomy and Horticulture, University of Nebraska, \\ Lincoln, NE 68583 \\ ${ }^{2}$ USDA-Agricultural Research Service, Northern Great \\ Plains Research Laboratory, P.O. Box 459, 1701 10th \\ Avenue, S.W., Mandan, ND 58554-0459
}

\begin{abstract}
Assessing effects of cropping systems on soil organic matter (SOM) and soil carbon (C) changes are necessary to make accurate projections regarding sequestration and emission of $\mathrm{CO}_{2}$ by agricultural soils. This process requires substantial annual management inputs and large outlays for soil sampling and analyses. Our objectives were (1) to evaluate and test an alternative method for soil organic matter determination, (2) to determine if crop rotation and $\mathrm{N}$ fertilizer management significantly affected soil organic matter at the beginning (1986) or after 12 yrs (1998), and (3) to determine if total soil organic matter levels have changed after 12 years in a long-term cropping
\end{abstract}

*Joint contribution of USDA-ARS and the Nebraska Agricultural Research Division, Lincoln, NE, as paper no. 13512.

${ }^{\dagger}$ Corresponding author. E-mail: gvarvel1@unl.edu 
system study. Soil samples were taken in 1986 and 1998 to a depth of $150 \mathrm{~cm}$ in $30 \mathrm{~cm}$ increments. Total soil organic $\mathrm{C}$ and organic matter by weight loss-on-ignition concentrations were determined for the soil samples taken in 1998. Results from both methods of analyses for the 1998 samples were highly correlated. No significant differences in soil organic matter by weight loss-onignition or total soil organic $\mathrm{C}$ concentrations between crop rotations or nitrogen $(\mathrm{N})$ fertilizer rates were obtained for either sampling date, in the change in soil organic matter concentrations between dates, or total soil $\mathrm{C}$ amounts in the profile $(0$ to $150 \mathrm{~cm})$ after 12 yrs (1998). Although no differences in soil organic matter (soil C) were obtained in the study, the excellent correlation between results of the two methods of organic matter analyses demonstrates that the less expensive and easier to use weight losson-ignition method can be used to make these types of assessments.

\section{INTRODUCTION}

Measurement of the long-term effects of crop and soil management practices on soil organic matter content provides necessary information to evaluate their effect on the environment. Soil and crop management can affect global balance of $\mathrm{CO}_{2}$ as soils serve as both a source and sink for this greenhouse gas. ${ }^{[1]}$ The mix of tillage practices used in 1990 for U.S. agriculture produced an emission rate of $8 \mathrm{MgCO}_{2} \mathrm{yr}^{-1}$ from soil organic matter. ${ }^{[2]}$ Trends toward reduced tillage and more diverse cropping systems should affect the magnitude of these emissions, but assessment of these affects on soil organic matter content must be continually monitored. This information can then be used to predict the effects of cropping and tillage systems on degradation, maintenance, or improvement of soil organic matter and the resulting sequestration or emission of $\mathrm{CO}_{2}$ by agricultural soils.

The significance of soil organic matter and its affect on long-term sustainability of croplands (maintenance or improvement) is well documented. ${ }^{[3]}$ Doran and Parkin ${ }^{[4]}$ included it as a major component of a required minimum data set in their definition of soil quality. All soils have various levels of quality, which are basically defined by stable natural or inherent features related to soil forming factors, and the loss of soil organic matter generally results in a reduction in soil quality. Measurement of soil organic matter then becomes a requirement before soil quality assessments can be made. This process is both difficult and 
costly because of the amount of organic matter present in soils and the time required for management practices to change soil organic matter levels.

This is especially apparent when the need to make assessments of the effect of crop and soil management on soil organic matter arises. Experiments must be conducted over a period of time long enough for the management treatments to reach some sort of equilibrium with respect to both crop and soil responses. Usually this requires a greater amount of time with respect to soil response variables than it does for crop responses. Long-term experiments necessary to make these types of determinations are expensive, difficult to maintain, and generally are comprised of several crop or soil management treatments. Together, these requirements mean that large numbers of soil samples are generated to determine the effect of management on soil organic matter levels.

Determination of soil organic matter for large numbers of samples from these types of studies has generally been done in recent years using automated dry combustion technology. This method is accurate and precise, but requires a large capital investment and technical expertise to run and maintain the equipment. More recently, Cambardella et al. ${ }^{[5]}$ proposed a less expensive and simpler modification of a weight loss-on-ignition method described by Schulte ${ }^{[6]}$ as an alternative to the automated dry combustion technique. This method requires only an accurate balance and high temperature oven, which for large numbers of samples offers promise for a dependable less costly alternative to routine soil $\mathrm{C}$ analyses.

Objectives of this study were (1) to evaluate and test an alternative method (less expensive and easier to use than total soil $\mathrm{C}$ combustion) for soil organic matter determination, (2) to determine if crop rotation and $\mathrm{N}$ fertilizer management significantly affected soil organic matter at the beginning (1986) or after 12 yrs (1998), and (3) to determine if total soil organic matter levels have decreased, maintained, or increased during the 12 years in any of the seven cropping systems compared in this study.

\section{MATERIALS AND METHODS}

A long-term cropping system experiment conducted on a Sharpsburg silty clay loam (fine, smectitic, mesic Typic Argiudoll) located on the Agronomy Farm at the University of Nebraska Agricultural Research and Development Center near Mead, Nebraska was used to assess management effects on soil properties over time. The study is comprised of seven cropping systems (three monoculture, two 2-yr, and two 4-yr rotations) with three rates of $\mathrm{N}$ fertilizer. Monocultures include continuous corn, continuous soybean, and continuous grain sorghum. Two-year rotations in the study are corn-soybean and grain 
sorghum-soybean and the two 4-yr rotations are corn-oat + clover-grain sorghum-soybean and corn-soybean-grain sorghum-oat + clover. Each phase of every rotation occurs every year for a total of 15 rotation treatments per replication. Additional information about agronomic practices throughout the duration of the study is presented in Varvel. ${ }^{[7]}$

Soil samples (1125) were taken every four years (1986, 1990, 1994, and 1998) throughout the duration of the study to evaluate and monitor the effects of rotations, crops in rotation, and $\mathrm{N}$ rates on selected soil properties. Four cores ( $3.3 \mathrm{~cm}$ diameter) were taken from each $\mathrm{N}$ subplot to a depth of $150 \mathrm{~cm}$ in $30 \mathrm{~cm}$ increments. These four cores were composited by depth, hand crushed and mixed, and the entire sample was put into plastic bags. All samples were weighed for bulk density determination and a subsample was taken for moisture content. The remaining part of the sample was air dried and then ground to pass a $2 \mathrm{~mm}$ screen. Samples of interest in this manuscript were the 1125 taken in both 1986 and 1998.

Soil samples from 1998 were used to determine total soil C and N levels present after several years of management in the seven cropping systems described above. A subsample was taken for total $\mathrm{C}$ and $\mathrm{N}$ analyses using an automatic $\mathrm{C}$ and $\mathrm{N}$ analyzer interfaced with a continuous-flow mass spectrometer for purposes of routine analyses according to the procedure described by Schepers et al. ${ }^{[8]}$ Total $\mathrm{C}$ from these samples was considered to be total organic $\mathrm{C}$, unless $\mathrm{pH}$ of the sample was 7.0 or greater, at which time they were analyzed for inorganic $\mathrm{C}$ (carbonates) with $1.5 \mathrm{~N}$ hydrochloric acid. ${ }^{[9]}$ Total $\mathrm{C}$ in those samples was then converted to total organic $\mathrm{C}$ by subtracting the inorganic $\mathrm{C}$ present. All values reported for total organic $\mathrm{C}$ concentrations were expressed on a gravimetric basis. An additional subsample was taken from each of the 1998 soil samples and analyzed for organic matter by weight loss-on-ignition (LOI) method. ${ }^{[5]}$ This method was less expensive and easier to use because it involved only heating the sample to $450^{\circ} \mathrm{C}$ for 4 -hr in a muffle furnace and weighing before and after the 4-hr heating time on an analytical balance.

Soil samples taken after the 1986 growing season were initially analyzed for total Kjeldahl $\mathrm{N}$ using the automatic block digestor method ${ }^{[10]}$ and inorganic (nitrate- and ammonium-N) and then archived. Our interest in management effects on soil organic $\mathrm{C}$ changes over time prompted removal of these samples from the archives for organic $\mathrm{C}$ analyses. Samples were analyzed for organic matter by the weight loss-on-ignition method ${ }^{[5]}$ so that results could be compared to those from samples taken in 1998.

Total soil organic $\mathrm{C}$ and organic matter by weight loss-on-ignition in the 1998 soil samples, organic matter by weight loss-on-ignition in the 1986 soil samples, and the change in organic matter by weight loss-on-ignition between 1986 and 1998 were analyzed using the Statistical Analyses System ${ }^{[11]}$ to determine if management effects were significant. 


\section{RESULTS AND DISCUSSION}

Automated analyses for total $\mathrm{C}$ in soils are expensive for long-term studies like this one where large numbers of samples are collected. We felt that with the large number of samples (1125) that were collected from this study every time it is sampled that a cheaper method was necessary. We also felt that because we had already determined total organic $\mathrm{C}$ levels for the samples taken in 1998, these same samples could be used to test an alternative method for soil organic C determination. One method recently re-evaluated for organic matter determination by weight loss-on-ignition ${ }^{[5]}$ seemed to be an excellent possibility. This method was chosen because it requires only an accurate analytical balance and muffle furnace, both of which are usually available in most analytical laboratories.

Samples from 1998 were used to make the comparison between the two methods. Figure 1 shows the relationship between total organic $\mathrm{C}$ and weight loss-on-ignition organic matter results for the 1998 soil samples. Similar to results obtained by Cambardella et al., ${ }^{[5]}$ a highly significant relationship between the two methods was obtained. Total soil organic $\mathrm{C}$ analyses were highly correlated $\left(\mathrm{r}^{2}=0.88\right)$ with weight loss-on-ignition soil organic matter analyses. Raw data was not converted to a volumetric basis since this is not needed where correlations are made. The relationship between results for the two methods indicated organic matter by weight loss-on-ignition was approximately $45 \%$ organic $\mathrm{C}$ for these soils. Cambardella et al. ${ }^{[5]}$ found for the range of soils they used that weight loss-on-ignition organic matter was approximately $53 \%$ organic C. The soil organic matter by weight loss-on-ignition values in the Cambardella et al. ${ }^{[5]}$ study ranged from 28.6 to $63.3 \mathrm{~g} \mathrm{~kg}^{-1}$ and from 7.2 to $25.1 \mathrm{~g} \mathrm{C} \mathrm{kg}^{-1}$ for soil organic C. Our values ranged from 1.5 to $47.5 \mathrm{~g} \mathrm{~kg}^{-1}$ for organic matter by

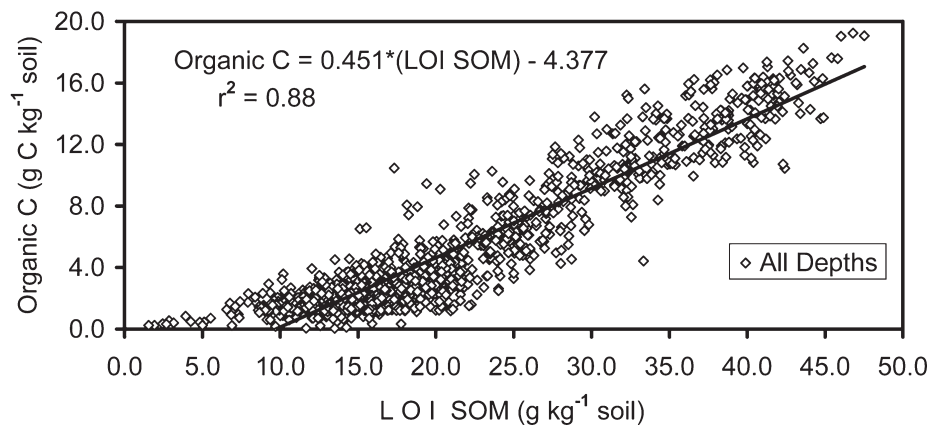

Figure 1. Relationship between organic C by dry combustion and soil organic matter (SOM) determined by weight loss-on-ignition for soil samples taken in $30-\mathrm{cm}$ increments to a depth of $150 \mathrm{~cm}$ in 1998 from a long-term cropping study at Mead, NE. 
weight loss-on-ignition and from 0.1 to $19.2 \mathrm{~g} \mathrm{C} \mathrm{kg}^{-1}$ for soil organic C. Our ranges were slightly larger than those of Cambardella et al., ${ }^{[5]}$ but the values tended to be lower on both scales. This was mainly due to the fact that for their study they used only surface soils $(0$ to $7.5 \mathrm{~cm})$ where levels of organic matter are greater while in our study we sampled the rooting profile in $30 \mathrm{~cm}$ increments to a depth of $150 \mathrm{~cm}$. In either case, the results were similar and showed that organic matter by weight loss-on-ignition was highly correlated to soil organic $\mathrm{C}$ and could be used to monitor the effects of management on $\mathrm{C}$ loss or deposition.

Because of these results, archived soil samples taken after completion of the first full rotation cycle in 1986 were analyzed for organic matter using the weight loss-on-ignition method. The high correlation between these two measures of soil organic matter for the 1998 samples indicated either method could be used to make organic matter assessments, and because of this we used the much simpler and less expensive weight loss-on-ignition method on the 1986 samples.

The second objective was to determine if rotation or $\mathrm{N}$ fertilizer management significantly affected either total soil organic C levels in 1998 or soil organic matter levels by weight loss-on-ignition in either 1998 or 1986 at any depth in the profile. Results were analyzed using the PROC MIXED procedure in

Table 1. Total Soil Organic C Concentrations in Each Rotation at Five Depths in 1998 at Mead, NE

\begin{tabular}{|c|c|c|c|c|c|c|}
\hline \multirow[b]{2}{*}{ Rotation $^{\mathrm{a}}$} & & \multicolumn{5}{|c|}{ Depth $(\mathrm{cm})$} \\
\hline & & $0-30$ & $30-60$ & $60-90$ & $90-120$ & $120-150$ \\
\hline & & \multicolumn{5}{|c|}{$\mathrm{C}\left(\mathrm{g} \mathrm{kg}^{-1}\right)$} \\
\hline $\mathrm{CC}$ & & 11.9 & 5.1 & 2.8 & 2.1 & 1.7 \\
\hline CSB & & 13.2 & 7.1 & 4.5 & 3.4 & 2.3 \\
\hline CSG & & 12.7 & 5.9 & 3.2 & 2.1 & 1.6 \\
\hline $\mathrm{C}-\mathrm{SB}$ & & 12.8 & 7.4 & 4.9 & 3.6 & 2.5 \\
\hline $\mathrm{SG}-\mathrm{SB}$ & & 11.8 & 5.3 & 3.0 & 2.0 & 1.8 \\
\hline $\mathrm{C}-\mathrm{OCL}-\mathrm{SG}-\mathrm{SB}$ & & 13.6 & 7.3 & 4.6 & 3.4 & 2.4 \\
\hline $\mathrm{C}-\mathrm{SB}-\mathrm{SG}-\mathrm{OCL}$ & & 13.2 & 7.1 & 4.5 & 3.2 & 2.2 \\
\hline Standard error & & 0.8 & 0.8 & 0.6 & 0.5 & 0.4 \\
\hline Source of variation & $\mathrm{df}$ & \multicolumn{5}{|c|}{$F$ values } \\
\hline Rotation & 6 & 1.09 & 1.49 & 2.15 & 2.41 & 1.22 \\
\hline $\mathrm{N}$ treatment & 2 & 0.48 & 3.02 & 2.86 & 1.98 & 2.92 \\
\hline Rotation $\times \mathrm{N}$ treatment & 12 & 0.65 & 0.76 & 0.56 & 0.96 & 1.07 \\
\hline
\end{tabular}


Statistical Analyses System. ${ }^{[12]}$ These analyses indicated that neither cropping systems nor $\mathrm{N}$ fertilizer rates significantly affected total organic $\mathrm{C}$ (Table 1) or weight loss-on-ignition organic matter values in 1998 (Table 2) or weight losson-ignition organic matter values in 1986 (Table 3) at any depth.

The final objective of our study was to use these results to determine if any changes in organic matter deposition or loss had occurred during the 12 years between the two sampling events in any of the seven cropping systems. Analyses were conducted by depth on the change in organic matter concentration between the 1998 and 1986 weight loss-on-ignition organic matter results. No significant differences between cropping systems or $\mathrm{N}$ fertilizer rate were obtained at any depth (Table 4). Similarly, when total $\mathrm{N}$ values determined by the Kjeldahl method on the 1986 samples were compared to total $\mathrm{N}$ values determined by the $\mathrm{C}$ and $\mathrm{N}$ analyzer on the 1998 samples, the total $\mathrm{N}$ values from the two different analytical methods were essentially equal as was shown by the regression equation and its $r^{2}$ (Fig. 2). As would be expected given these results, analyses of the differences between the $\mathrm{N}$ values for the 12-year period indicated no changes had occurred (data not shown).

Table 2. Total Soil Organic Matter Concentrations by Weight Loss-on-Ignition in Each Rotation at Five Depths in 1998 at Mead, NE

\begin{tabular}{|c|c|c|c|c|c|c|}
\hline \multirow[b]{2}{*}{ Rotation $^{\mathrm{a}}$} & & \multicolumn{5}{|c|}{ Depth (cm) } \\
\hline & & $0-30$ & $30-60$ & $60-90$ & $90-120$ & $120-150$ \\
\hline & & \multicolumn{5}{|c|}{ Organic matter $\left(\mathrm{g} \mathrm{kg}^{-1}\right)$} \\
\hline $\mathrm{CC}$ & & 34.8 & 21.4 & 16.2 & 14.5 & 13.7 \\
\hline CSB & & 36.9 & 26.5 & 20.8 & 18.0 & 15.8 \\
\hline CSG & & 37.9 & 25.6 & 19.4 & 17.1 & 15.6 \\
\hline $\mathrm{C}-\mathrm{SB}$ & & 35.9 & 26.7 & 20.8 & 17.9 & 16.9 \\
\hline SG-SB & & 34.0 & 21.7 & 16.5 & 14.3 & 13.4 \\
\hline $\mathrm{C}-\mathrm{OCL}-\mathrm{SG}-\mathrm{SB}$ & & 38.0 & 26.6 & 20.3 & 17.6 & 15.8 \\
\hline $\mathrm{C}-\mathrm{SB}-\mathrm{SG}-\mathrm{OCL}$ & & 35.6 & 25.1 & 19.3 & 16.4 & 14.7 \\
\hline Standard error & & 1.7 & 2.0 & 1.7 & 1.4 & 1.4 \\
\hline Source of variation & $\mathrm{df}$ & \multicolumn{5}{|c|}{$F$ value } \\
\hline Rotation & 6 & 1.21 & 1.46 & 1.45 & 1.46 & 1.09 \\
\hline $\mathrm{N}$ treatment & 2 & 0.34 & 2.01 & 2.96 & 2.29 & 2.26 \\
\hline Rotation $\times \mathrm{N}$ treatment & 12 & 0.25 & 0.91 & 1.04 & 0.90 & 1.83 \\
\hline
\end{tabular}


Table 3. Total Soil Organic Matter Concentrations by Weight Loss-on-Ignition in Each Rotation at Five Depths in 1986 at Mead, NE

\begin{tabular}{|c|c|c|c|c|c|c|}
\hline \multirow[b]{2}{*}{ Rotation $^{\mathrm{a}}$} & & \multicolumn{5}{|c|}{ Depth $(\mathrm{cm})$} \\
\hline & & $0-30$ & $30-60$ & $60-90$ & $90-120$ & $120-150$ \\
\hline & & \multicolumn{5}{|c|}{ Organic matter $\left(\mathrm{g} \mathrm{kg}^{-1}\right)$} \\
\hline $\mathrm{CC}$ & & 36.0 & 22.5 & 17.6 & 14.7 & 13.7 \\
\hline CSB & & 37.3 & 26.1 & 20.0 & 17.0 & 14.9 \\
\hline CSG & & 38.3 & 25.5 & 19.4 & 16.5 & 13.6 \\
\hline $\mathrm{C}-\mathrm{SB}$ & & 35.6 & 25.5 & 19.6 & 16.5 & 14.7 \\
\hline $\mathrm{SG}-\mathrm{SB}$ & & 35.7 & 23.1 & 17.2 & 13.9 & 13.1 \\
\hline $\mathrm{C}-\mathrm{OCL}-\mathrm{SG}-\mathrm{SB}$ & & 38.5 & 26.9 & 20.8 & 17.3 & 15.5 \\
\hline $\mathrm{C}-\mathrm{SB}-\mathrm{SG}-\mathrm{OCL}$ & & 37.5 & 26.1 & 20.1 & 16.6 & 15.3 \\
\hline Standard error & & 2.1 & 2.2 & 1.6 & 1.4 & 1.3 \\
\hline Source of variation & $\mathrm{df}$ & \multicolumn{5}{|c|}{$F$ value } \\
\hline Rotation & 6 & 0.69 & 0.76 & 0.98 & 1.11 & 1.18 \\
\hline $\mathrm{N}$ treatment & 2 & 1.33 & 1.09 & 3.00 & 2.68 & 2.06 \\
\hline Rotation $\times \mathrm{N}$ treatment & 12 & 0.68 & 0.60 & 0.46 & 1.12 & 1.89 \\
\hline
\end{tabular}

${ }^{\mathrm{a}} \mathrm{CC}$, continuous corn; $\mathrm{CSB}$, continuous soybean; $\mathrm{CSG}$, continuous grain sorghum; $\mathrm{C}-\mathrm{SB}$, corn-soybean; SG-SB, grain sorghum-soybean; C-OCL-SG-SB, corn-oat + clover-grain sorghum-soybean; C-SB-SG-OCL, corn-soybean-grain sorghumoat + clover.

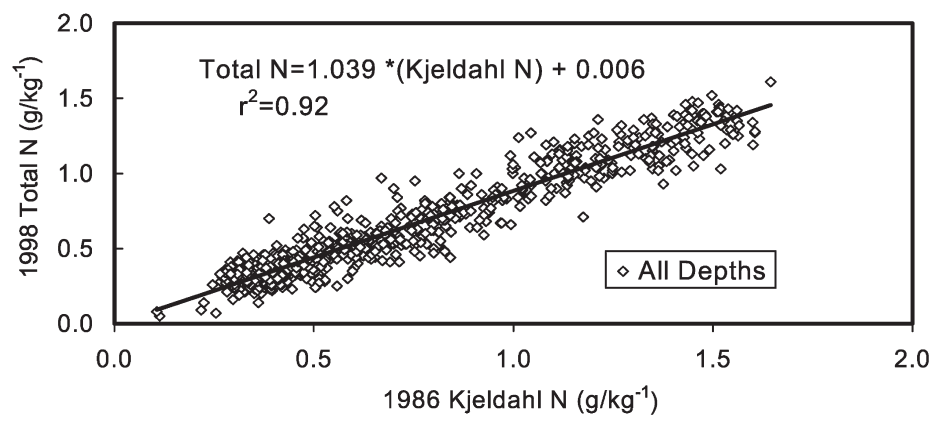

Figure 2. Relationship between total N by dry combustion for 1998 soil samples and total $\mathrm{N}$ by the Kjeldahl method for 1986 soil samples, both taken in 30-cm increments to a depth of $150 \mathrm{~cm}$ from a long-term cropping system study at Mead, NE. 
Table 4. Difference in Total Soil Organic Matter Concentrations by Weight Loss-onIgnition Between 1986 and 1998 in Each Rotation at Five Depths in 1998 at Mead, NE

\begin{tabular}{|c|c|c|c|c|c|c|}
\hline \multirow[b]{2}{*}{ Rotation $^{a}$} & & \multicolumn{5}{|c|}{ Depth $(\mathrm{cm})$} \\
\hline & & $0-30$ & $30-60$ & $60-90$ & $90-120$ & $120-150$ \\
\hline & & \multicolumn{5}{|c|}{ Organic matter $\left(\mathrm{g} \mathrm{kg}^{-1}\right)$} \\
\hline $\mathrm{CC}$ & & -1.2 & -1.1 & -1.4 & -0.2 & 0.0 \\
\hline CSB & & -0.4 & 0.4 & 0.8 & 1.0 & 0.9 \\
\hline CSG & & -0.4 & 0.1 & 0.0 & 0.6 & 2.0 \\
\hline $\mathrm{C}-\mathrm{SB}$ & & 0.3 & 1.2 & 1.2 & 1.5 & 2.2 \\
\hline SG-SB & & -1.7 & -1.4 & -0.8 & 0.4 & 0.3 \\
\hline $\mathrm{C}-\mathrm{OCL}-\mathrm{SG}-\mathrm{SB}$ & & -0.5 & -0.3 & -0.5 & 0.3 & 0.3 \\
\hline $\mathrm{C}-\mathrm{SB}-\mathrm{SG}-\mathrm{OCL}$ & & -1.6 & -1.0 & -0.8 & -0.1 & -0.6 \\
\hline Standard error & & 1.9 & 1.6 & 1.5 & 1.4 & 1.3 \\
\hline Source of variation & $\mathrm{df}$ & \multicolumn{5}{|c|}{$F$ value } \\
\hline Rotation & 6 & 0.37 & 0.92 & 0.76 & 0.32 & 1.28 \\
\hline $\mathrm{N}$ treatment & 2 & 0.37 & 1.00 & 0.21 & 1.21 & 0.01 \\
\hline Rotation $\times \mathrm{N}$ treatment & 12 & 0.60 & 0.77 & 0.90 & 0.88 & 1.31 \\
\hline
\end{tabular}

${ }^{a} \mathrm{CC}$, continuous corn; $\mathrm{CSB}$, continuous soybean; $\mathrm{CSG}$, continuous grain sorghum; $\mathrm{C}-\mathrm{SB}$, corn-soybean; SG-SB, grain sorghum-soybean; C-OCL-SG-SB, corn-oat + clovergrain sorghum-soybean; C-SB-SG-OCL, corn-soybean-grain sorghum-oat + clover.

These results were different than those reported by Varvel ${ }^{[13]}$ from this same study where changes in total $\mathrm{C}$ were obtained between cropping systems and $\mathrm{N}$ fertilizer rates between 1984 and 1992. The apparent disparity between these two sets of results was not surprising, especially when they are examined closely. Changes in total soil C reported in Varvel ${ }^{[13]}$ were for the surface $15 \mathrm{~cm}$ depth, while these results are for the surface $30 \mathrm{~cm}$ depth and deeper. It would appear that the majority of organic matter deposition or loss was occurring in the surface $15 \mathrm{~cm}$ in an experiment such as the one reported here.

Our final examination was to determine the amount of soil organic $\mathrm{C}$ for the entire profile in 1998. Total soil organic $\mathrm{C}$ was determined for each depth using bulk density and soil organic C concentration results for 1998 and then summed over all depths. Similar to results above, no significant differences between cropping systems or $\mathrm{N}$ fertilizer rates were obtained for total organic $\mathrm{C}$ by depth or in the surface $150 \mathrm{~cm}$ in this experiment (Table 5). This was expected since analyses of soil organic C concentrations in 1998 (Table 1) and bulk density results (data not shown) for the various depths were not significantly affected by cropping system or $\mathrm{N}$ fertilizer rate. 
Table 5. Total Soil Organic C in Each Rotation at the 0-30, 30-60, 60-90, 90-120, and $120-150 \mathrm{~cm}$ Depths in 1998 at Mead, NE

\begin{tabular}{|c|c|c|c|c|c|c|c|}
\hline \multirow[b]{2}{*}{ Rotation $^{\mathrm{a}}$} & & \multicolumn{6}{|c|}{ Depth $(\mathrm{cm})$} \\
\hline & & $0-30$ & $30-60$ & $60-90$ & $90-120$ & $120-150$ & Total \\
\hline & & \multicolumn{6}{|c|}{ Organic C $\left(\mathrm{Mg} \mathrm{ha}^{-1}\right)$} \\
\hline $\mathrm{CC}$ & & 47.2 & 19.3 & 10.6 & 6.8 & 6.3 & 90.1 \\
\hline CSB & & 50.4 & 26.4 & 16.9 & 12.3 & 9.0 & 115.1 \\
\hline CSG & & 50.0 & 22.7 & 12.2 & 6.9 & 6.0 & 97.6 \\
\hline $\mathrm{C}-\mathrm{SB}$ & & 49.9 & 27.3 & 17.6 & 13.3 & 10.0 & 118.0 \\
\hline SG-SB & & 46.6 & 20.4 & 11.3 & 6.4 & 6.7 & 91.4 \\
\hline $\mathrm{C}-\mathrm{OCL}-\mathrm{SG}-\mathrm{SB}$ & & 52.7 & 27.0 & 16.6 & 11.9 & 9.3 & 117.5 \\
\hline $\mathrm{C}-\mathrm{SB}-\mathrm{SG}-\mathrm{OCL}$ & & 51.0 & 26.4 & 16.7 & 12.1 & 8.6 & 114.8 \\
\hline Standard error & & 2.8 & 2.9 & 2.3 & 2.1 & 1.5 & 10.3 \\
\hline Source of variation & $\mathrm{df}$ & \multicolumn{6}{|c|}{$F$ values } \\
\hline Rotation & 6 & 0.79 & 1.30 & 1.74 & 2.27 & 1.38 & 1.53 \\
\hline $\mathrm{N}$ treatment & 2 & 1.43 & 3.38 & 2.68 & 3.20 & 4.89 & 3.28 \\
\hline Rotation $\times \mathrm{N}$ treatment & 12 & 0.91 & 0.66 & 0.61 & 1.12 & 1.06 & 0.82 \\
\hline
\end{tabular}

${ }^{\mathrm{a}} \mathrm{CC}$, continuous corn; $\mathrm{CSB}$, continuous soybean; $\mathrm{CSG}$, continuous grain sorghum; $\mathrm{C}-\mathrm{SB}$, corn-soybean; SG-SB, grain sorghum-soybean; C-OCL-SG-SB, Corn-oat + clovergrain sorghum-soybean; C-SB-SG-OCL, Corn-soybean-grain sorghum-oat + clover.

Another component in the system that needs to be considered is the effects of these management systems on inorganic $\mathrm{C}$ levels (calcium carbonate), especially with the acidification effects of the $\mathrm{N}$ fertilizer treatments in these cropping systems. Carbonates are present at this experimental location, but only at depths greater than $60 \mathrm{~cm}$ in less than $10 \%$ of the experimental units. Our analyses of the effects of these treatments on the acidification and the resulting loss of $\mathrm{C}$ from calcium carbonates at these depths showed no effects of cropping system or fertilizer $\mathrm{N}$ management (data not shown). Measurement of $\mathrm{pH}$ in the surface $15 \mathrm{~cm}$ of soils in this experiment shows that acidification is occurring at different rates depending upon the cropping system/ $\mathrm{N}$ fertilizer combinations, ${ }^{[14]}$ indicating care must be taken and carbonates considered when they occur in the surface soils where acidification may be occurring.

\section{CONCLUSIONS}

The highly significant relationship between total organic $\mathrm{C}$ and weight losson-ignition organic matter in this long-term study demonstrated that the less 
expensive and easier to use weight loss-on-ignition method ${ }^{[5]}$ could be used to make organic matter assessments in both surface and subsurface soils. This becomes extremely important in long-term experiments such as this one because of the large number of treatment comparisons and the concurrent large number of samples collected each time the experiment is sampled. It also makes a method for organic matter assessment in soils available to a greater number of people, especially in developing countries.

\section{REFERENCES}

1. CAST, Preparing U.S. Agriculture for Global Climate Change; Task Force Rep. No. 119, Council for Agricultural Science and Technology: Ames, IA, 1992.

2. EPA, The Impact of Conservation Tillage Use on Soil and Atmospheric Carbon in the Contiguous United States; EPA/600/3-91/056, U.S. Environmental Protection Agency: Washington, DC, 1991.

3. Follett, R.F. Soil Management Concepts and Carbon Sequestration in Cropland Soils. Soil Till. Res. 2001, 61, 77-92.

4. Doran, J.W.; Parkin, T.B. Quantitative Indicators of Soil Quality: A Minimum Data Set. In Methods for Assessing Soil Quality, SSSA Spec. Publ. 49; Doran, J.W., Jones, A.J., Eds.; Soil Science Society of America: Madison, WI, 1996; 25-37.

5. Cambardella, C.A.; Gajda, A.M.; Doran, J.W.; Wienhold, B.J.; Kettler, T.A. Estimation of Particulate and Total Organic Matter by Weight Losson-Ignition. In Assessment Methods for Soil Carbon; Lal, R., Kimble, J.F., Follett, R.F., Stewart, B.A., Eds.; CRC Press/Lewis Publishers: Boca Raton, FL, 2001; 349-359.

6. Schulte, E.E. Recommended Soil Organic Matter Tests. In Recommended Chemical Soil Test Procedures for the North Central Region, NCR Publ. No. 221 (rev.); Danke, W.C., Ed.; Cooperative Extension Service, North Dakota State University: Fargo, ND, 1988; 29-31.

7. Varvel, G.E. Crop Rotation and Nitrogen Effects on Normalized Grain Yields in a Long-Term Study. Agron. J. 2000, 92, 938-941.

8. Schepers, J.S.; Francis, D.D.; Thompson, M.T. Simultaneous Determination of Total C, Total N, and ${ }^{15} \mathrm{~N}$ on Soil and Plant Material. Commun. Soil Sci. Plant Anal. 1989, 20, 949-959.

9. Gajda, A.M.; Doran, J.W.; Wienhold, B.J.; Kettler, T.A.; Pikul, J.L.; Cambardella, C.A. Soil Quality Evaluations of Alternative and Conventional Management Systems in the Great Plains. In Assessment Methods for Soil Carbon; Lal, R., Kimble, J.F., Follett, R.F., Stewart, B.A., Eds.; CRC Press/Lewis Publishers: Boca Raton, FL, 2001; 381-400. 
10. Schuman, G.E.; Stanley, M.A.; Knudsen, D. Automated Total Nitrogen Analysis of Soil and Plant Samples. Soil Sci. Soc. Am. Proc. 1973, 37 (3), 480-481.

11. SAS/STAT, SAS/STAT User's Guide, 4th Ed.; SAS Institute, Inc.: Cary, NC, 1992.

12. Littell, R.C.; Milliken, G.A.; Stroup, W.W.; Wolfinger, R.D. SAS ${ }^{\circledR}$ System for Mixed Models; SAS Institute, Inc.: Cary, NC, 1996.

13. Varvel, G.E. Rotation and Nitrogen Fertilization Effects on Changes in Soil Carbon and Nitrogen. Agron. J. 1994, 86 (2), 319-325.

14. Liebig, M.A.; Varvel, G.E.; Doran, J.W.; Wienhold, B.J. Crop Sequence and N Fertilization Effects on Soil Properties in the Western Corn Belt. Agron. J. 2002, 93, in press. 